Génét. Sél. Evol., 1985, 17 (2), 251-264

\title{
Selection for large and small litter size of the first three litters in mice
}

\author{
L.F. de la FUENTE and F. SAN PRIMITIVO \\ Departamento de Genética. Facultad de Veterinaria. Universidad de León. \\ León, Spain
}

\begin{abstract}
Summary
A selection experiment based on female performance in 2 lines, $\mathrm{L}+$ for increased and L- for decreased total number of young born alive in the first 3 births (TNY-3) was conducted for 8 generations. Line $C$, served as an unselected control. All litters were standardized to 8 mice. Responses and correlated responses were measured as a deviation from the control line. Heritability estimates for TNY-3 were $0.24 \pm 0.10$ from twice the dam-daughter regression and $0.13 \pm 0.15$ from the interclass correlations among half-sib families. After 8 generations of selection, the cumulated response was 3.80 young in the $\mathrm{L}+$ line and -3.44 in the $\mathrm{L}-$ line. Realized heritabilities for TNY-3 were $0.28 \pm 0.05$ in the $\mathrm{L}+$ line, $0.21 \pm 0.05$ in $\mathrm{L}^{-}$line and $0.24 \pm 0.03$ for divergence. Realized genetic correlations were $0.82 \pm 0.08$ between TNY-3 and first litter size, $0.50 \pm 0.12$ between TNY-3 and second litter size and $0.60 \pm 0.11$ between TNY-3 and third litter size. Correlated responses per generation were $0.12 \pm 0.07 \mathrm{~g}$ and $-0.22 \pm 0.13 \mathrm{~g}$ for 6 week body weight in the $\mathrm{L}+$ and $\mathrm{L}$ - lines respectively. Realized genetic correlations were $0.50 \pm 0.13$ between TNY-3 and 3-week body weight and $0.65 \pm 0.04$ between TNY-3 and 6-week body weight.
\end{abstract}

Key words : Mice, litter size, selection, heritability.

\begin{abstract}
Résumé
Sélection divergente sur la prolificité chez la souris à partir des résultats des trois premières mises bas
\end{abstract}

Cette étude concerne une expérience de sélection sur la prolificité conduite chez la souris pendant 8 générations. Une sélection divergente $\left(\mathrm{L}^{+}, \mathrm{L}^{-}\right)$avec témoin (C) a été réalisée sur les performances des femelles (nombre total de nés vivants) lors de leurs 3 premières mises bas. La taille des portées était standardisée à 8 après la mesure de celle-ci. Les réponses directes et corrélées à la sélection ont été mesurées à partir des écarts à la lignée témoin. La réponse à la sélection après 8 générations était de 3,80 nés dans la lignée haute $\left(\mathrm{L}^{+}\right)$et -3.44 dans la lignée basse $\left(\mathrm{L}^{-}\right)$. L'héritabilité du nombre de nés totaux (TNY-3) a été estimée à $0,24 \pm 0,10$ par le double de la régression mère-fille et $0,13 \pm 0,15$ à partir de la corrélation entre demi-germains. Pour ce mểme caractère, la valeur réalisée était de $0,28 \pm 0,05$ dans la lignée haute $\left(\mathrm{L}^{+}\right), 0,21 \pm 0,05$ dans la lignée basse $\left(\mathrm{L}^{-}\right)$et 
$0,24 \pm 0,03$ sur les écarts entre ces 2 lignées. Les réponses corrélées par génération sur le poids à 6 semaines étaient de $0,12 \pm 0,07 \mathrm{~g}$ et $-0,22 \pm 0,13 \mathrm{~g}$ dans les lignées haute et basse respectivement. La corrélation génétique réalisée entre le nombre total de nés et la prolificité aux $1^{\mathrm{res}}, 2^{\mathrm{es}}$ et $3^{\mathrm{es}}$ mises bas a été estimée à $0,82 \pm 0,08 ; 0,50 \pm 0,12$ et $0,60 \pm 0,11$. Entre le nombre total de nés et le poids, elle était de $0,50 \pm 0,13$ et $0,63 \pm 0,04$ à 3 et 6 semaines respectivement.

Mots clés : Souris, taille de portée, sélection, héritabilité.

\section{Introduction}

Litter size is a quantitative character of considerable complexity, determined by ovulation rate, zygotic survival, implantation, embryonic viability, parturition and postpartum survival of the young (ROBERTS, 1965). Many selection experiments for litter size in mice have been carried out (FALCONER, 1960 b ; DALTON \& BYWATER, 1963 ; BAteman, 1966 ; Bradford, 1968 ; EKLUnd \& BradFord, 1977 ; BaKKer et al., 1978 and EISEN, 1978), but in all of them the selection criterion was litter size at first parity. However, litter size at first birth may not be representative of litter size at subsequent parities. Selection for first litter size increases litter size at first birth, but with a permanent breeding method (i.e. males left continously with females), litters are not increased at subsequent births (WALLINGA \& BAKKER, 1978). No selection experiments have been reported for fertility based on the size of several litters. In the present study selection was based on the number of young born alive in the first 3 births in mice, to compare it with selection experiments for litter size at first birth. The genetics of litter size in mice and multiparous farm livestock (rabbit, pigs) is similar. Besides, the improvement of prolificacy in the latter is generally based on several births. Thus the results of this experiment could be considered as predictors of possible results in farm livestock.

The objectives of the present study were : a) to determine the realized heritability of litter size (TNY-3) ; b) to evaluate the efficiency of selection for prolificacy based on total litter size of the first 3 births, and c) to evaluate the correlated responses and realized genetic correlations of reproductive traits with body weight. Selection for litter size is known to affect body weight through its correlation with ovulation rate (KENNEDY \& KENNEDY, 1972).

\section{Materials and methods}

The mice used in this experiment came from a non-inbred population of the NMRI strain. This base population (150 pairs) was divided into 3 lines, $\mathrm{L}^{+}, \mathrm{L}^{-}$and $\mathrm{C}$, with 50 pairs per line. Individual selection based on the number of young born alive in the first 3 births (TNY-3) was conducted in 2 lines, $\mathrm{L}^{+}$for increased fertility and $\mathrm{L}^{-}$ for decreased fertility. Line $\mathrm{C}$, an unselected control, was used to adjust for possible environmental changes. The 3 lines were maintained with 50 mating pairs per generation. A mating system of maximum avoidance of inbreeding was applied in line $\mathrm{C}$ where one male and female were randomly chosen from each litter. 
Individual selection in $\mathrm{L}^{+}$and $\mathrm{L}^{-}$lines was conducted only for females. Males were randomly selected. Females which did not produce 3 litters in a period of 85 days were not considered for selection. This study included 8 generations of selection. In each generation, the best 13-17 females in each selected line were chosen. First litter progeny from the selected females provided the 50 females and 50 males constituting the next generation. Males and females were pair-mated randomly at 50 to 60 days of age with the avoidance of full-sib mating. One female and one male were cohabited countinuously during a period of 85 days. Mice were mated on the same day in order to synchronize the 1 st birth in each generation, avoiding the female age effect on litter size in the next generation (KENNEDY \& KENNEDy, 1972).

At 2 days of age, the number of young was recorded and litters were standardized to 8 young, attempting to obtain 4 males and 4 females. Addition of young was made in litters with less than 8 young from litters of the same age and line. After weaning at 19 days of age, males and females were maintained separately. All mice were weighed individually at 3 and 6 weeks of age. Body weight is presented as the unweighted mean of males and females.

The management and environmental conditions in the animal house were similar for lines across generations. Temperature was kept at $21 \pm 1{ }^{\circ} \mathrm{C}$ with a lighting cycle of 12 hours light - 12 hours dark. The mice were fed SAndermus pellets ad libitum.

Estimates of genetic parameters. Heritabilities were estimated in the base population by 2 methods : a) from twice the regression of daughter on dam and b) from 4 times the intraclass correlation of half-sibs. Forty half-sibs families were analyzed. The family size was 4 dams per sire and 4 daughters per dam (RoberTson, 1959).

Variance components were estimated in a nested analysis of variance with unequal subclasses. The statistical model was :

$$
\mathrm{Y}_{\mathrm{ijk}}=\mu+\mathrm{S}_{\mathrm{i}}+\mathrm{D}_{\mathrm{j}(\mathrm{i})}+\mathrm{e}_{\mathrm{ijk}}
$$

where $Y_{i j k}$ is the record of the $k^{\text {th }}$ progeny of the $j^{\text {th }}$ dam mated to the $i^{\text {th }}$ sire ; $\mu$ is the mean; $S_{i}$ is the effect of $i^{\text {th }}$ sire $; D_{j(i)}$ is the effect of the $j^{\text {th }}$ dam mated to the $i^{\text {th }}$ sire and $e_{i j k}$ is the residual.

Variance components and standard errors of heritabilities $\left(h^{2}\right)$ were calculated following the formulae of BECKER (1967). The realized heritabilities for $\mathrm{L}^{+}, \mathrm{L}^{-}$and divergent selections were calculated by doubling the regression coefficient of direct response $(\mathrm{R})$ on cumulative selection differencial (SDa) up to generation 8 (FALconer, $1960 \mathrm{a}$ ). The realized selection differential (SDr) was calculated by weighting the litter size of each dam by the number of daugthers that survived till mating. The expected selection differential (SDe) was calculated as the difference between the average TNY-3 of selected females and the average TNY-3 of all the females at each generation. Standard errors of realized heritabilities were based on formulae of HiLL (1972 a, 1972 b).

Realized genetic correlation between 2 traits, when only one of them has been selected, was calculated using the formulae of RUTLEDGE et al. (1973) :

$$
r_{G r}=b_{C R / R}\left(h_{x} \sigma_{P x} / h_{y} \sigma_{P y}\right)
$$

where $b_{\mathrm{CR} / \mathrm{R}}$ is the realized genetic regression of correlated response in trait $y$ on direct response in trait $\mathrm{x}$. Standard errors of $\mathrm{r}_{\mathrm{Gr}}$ were calculated using the formulae of HILl (1971). 


\section{Results}

\section{A. Base population characteristics}

Before the selection experiment for fertility was started, phenotypic and genetic parameters of reproductive and body weight traits were estimated to predict the correlated and direct response to selection. These estimates also were used to decide on appropriate selection procedures. Means, phenotypic variances and coefficients of variation of reproductive traits estimated in the base population are shown in table 1 .

\section{TABLE 1}

Reproduction traits in the base population, NMRI strain.

Caractéristiques de reproduction de la population fondatrice, souche NMRI.

\begin{tabular}{|c|c|c|c|c|}
\hline Trait & $\begin{array}{c}\text { Sample } \\
\text { size }\end{array}$ & Mean & $\begin{array}{c}\text { Phenotypic } \\
\text { variance }\end{array}$ & $\begin{array}{l}\text { Coef. of } \\
\text { variation }\end{array}$ \\
\hline 1st litter size (FLS) ... & 155 & 11.35 & 9.24 & 0.26 \\
\hline 2nd litter size (SLS) $\ldots \ldots \ldots \ldots \ldots$ & 125 & 12.62 & 14.44 & 0.30 \\
\hline 3rd litter size (TLS) $\ldots \ldots \ldots \ldots \ldots$ & 75 & 12.62 & 9.30 & 0.24 \\
\hline TNY-3* $\ldots \ldots \ldots \ldots \ldots \ldots \ldots$ & 75 & 35.07 & 37.75 & 0.18 \\
\hline Cohabiting to 1 st birth (days) $\ldots$. & 155 & 22.61 & 30.24 & 0.24 \\
\hline 1st to 2 nd birth (days) .......... & 125 & 22.68 & 36.30 & 0.27 \\
\hline 2nd to 3 rd birth (days) $\ldots \ldots \ldots$ & 75 & 26.03 & 42.51 & 0.25 \\
\hline
\end{tabular}

* Total number of young born in the first 3 births.

Females used for breeding remained together ( 8 females in each cage) from weaning to mating. This system produced synchronization of the 1 st estrous cycle. The 87 p. 100 of females had their 1st litter in a period of time between the 19th and the 24th post-mating day. The synchronization for the 2 nd and 3rd parities was 83 p. 100 and 69 p. 100 respectively.

Estimates of heritabilities for litter size from daughterdam regression coefficients and from half-sib correlations are given in table 2. Heritability estimates for TNY-3 based on regression coefficients $(2 \mathrm{~b})$ were obtained with lower error and were comparable to realized heritabilities obtained by actual selection. Heritability estimates of first litter size were higher than $\mathrm{h}^{2}$ of 2 nd litter size. The heritability of the trait "total of several litters » was calculated following the formula given by BOLET \& Legault (1982) based on repeatability $(t), h^{2}$ in each litter and number of litters $(n)$ :

$$
\mathrm{h}_{\mathrm{s}}^{2}=\mathrm{nh}^{2} /[1+(\mathrm{n}-1) \mathrm{t}]
$$

The estimate of heritability for TNY-3 obtained by this formula was $0.26 \pm 0.10$ which was similar to $0.24 \pm 0.10$ and $0.24 \pm 0.03$, calculated from « $2 \mathrm{~b}$ » and the $\mathrm{h}_{\mathrm{r}}^{2}$ after the 8 generations of selection, respectively. 
TABLE 2

Estimates of heritability $\pm S . E$. from daugther-dam regression $(2 b)$ and the intraclass correlation among half-sib families $(4 t)$.

Estimation de l'héritabilité à partir de la régression mère-fille (2 b) et de la corrélation entre demi-frères (4t).

\begin{tabular}{|c|c|c|}
\hline \multirow{2}{*}{ Trait } & \multicolumn{2}{|c|}{ Method } \\
\hline & $4 \mathrm{t} \pm$ S.E. & $2 \mathrm{~b} \pm$ S.E. \\
\hline 1st litter size $\ldots \ldots \ldots \ldots \ldots \ldots \ldots$ & $0.21 \pm 0.17$ & $0.12 \pm 0.08$ \\
\hline 2nd litter size $\ldots \ldots \ldots \ldots \ldots \ldots \ldots$ & $0.11 \pm 0.13$ & $0.10 \pm 0.09$ \\
\hline 3rd litter size $\ldots \ldots \ldots \ldots \ldots \ldots \ldots$ & $0.07 \pm 0.20$ & $0.13 \pm 0.10$ \\
\hline TNY-3 $\ldots \ldots \ldots \ldots, \ldots, \ldots, \ldots$ & $0.13 \pm 0.15$ & $0.24 \pm 0.10$ \\
\hline
\end{tabular}

\section{B. Selection differential}

Realized selection differentials (SDr) and expected selection differentials (SDe) are shown in table 3. SDr decreased across generations and was very low in the 7 th and 8th generations. SDe was higher than SDr. The difference batween SDe and SDr was small in the $L^{+}$line $(40.00-39.35)$, but it was larger in $L^{-}(36.86-32.12)$. This difference (4.74) in the $L^{-}$line was due to a small litter size : fewer females were chosen from selected litters.

\section{TABLE 3}

Selection differential of number of young born in the 3 first litters.

Différentielle de sélection pour le nombre de nés vivants aux 3 premières mises bas.

\begin{tabular}{|c|c|c|c|c|c|c|c|c|c|}
\hline & Generation & 1 & 2 & 3 & 4 & 5 & 6 & 7 & 8 \\
\hline \multirow{2}{*}{$\mathbf{L}+$} & SDr & 6.97 & 5.54 & 7.07 & 5.94 & 3.02 & 4.31 & 4.21 & 2.29 \\
\hline & SDe & 6.93 & 6.36 & 6.70 & 5.90 & 3.83 & 4.19 & 3.73 & 2.41 \\
\hline \multirow{2}{*}{$\mathrm{L}-$} & SDr $\ldots \ldots$ & -4.89 & -4.68 & -6.11 & -4.20 & -3.38 & -4.00 & -2.75 & -2.11 \\
\hline & SDe & -5.71 & -6.22 & -7.02 & -5.41 & -3.29 & -3.69 & -2.95 & -2.60 \\
\hline
\end{tabular}

SDr : Realized selection differential.

SDe : Expected selection differential.

The selection intensity based on the percentage of females selected was low in both lines : 0.81 in the $L^{+}$line and 0.68 in the $L^{-}$line. The contributions of each parity to $\mathrm{SDr}$ are shown in table 4. In the early generations of selection, the contribution was similar among parities, but from the 5 th generation on the contribution of the 3 rd parity was lower than the others. 


\section{TABLE 4}

Contribution of each parity to the selection differential *.

Contribution de chaque mise bas à la différentielle de sélection.

\begin{tabular}{|c|c|c|c|c|c|c|c|c|c|c|}
\hline \multirow{2}{*}{ Line } & \multirow{2}{*}{ Parity } & \multicolumn{8}{|c|}{ Generation } & \\
\hline & & 1 & 2 & 3 & 4 & 5 & 6 & 7 & 8 & \\
\hline \multirow{3}{*}{$\mathbf{L}+$} & $1 \mathrm{st}$ & 1.63 & 0.68 & 2.66 & 2.06 & 2.29 & 2.02 & 1.60 & 1.86 & $41 \%$ \\
\hline & 2nd & 1.84 & 1.92 & 1.16 & 2.29 & 1.03 & 1.41 & 1.63 & 0.74 & $29 \%$ \\
\hline & $3 \mathrm{rd}$ & 1.89 & 2.88 & 3.62 & 1.65 & 0.42 & 0.06 & 0.40 & 0.20 & $30 \%$ \\
\hline \multirow{3}{*}{$\mathbf{L}^{-}$} & $1 \mathrm{st}$ & 1.89 & 0.51 & 1.86 & 1.94 & 1.78 & 2.01 & 0.87 & 1.90 & $33 \%$ \\
\hline & 2nd & 1.85 & 2.07 & 2.36 & 2.35 & 0.74 & 2.32 & 2.31 & 1.85 & $42 \%$ \\
\hline & $3 r d$ & 2.50 & 2.45 & 2.16 & 1.16 & 0.73 & 0.06 & 0.55 & -0.20 & $25 \%$ \\
\hline
\end{tabular}

* Estimated as the difference between the average litter size for each parity of selected females. and that of all females, in each generation.

\section{Direct response and realized heritability}

The changes in TNY-3 mean over generations in the $\mathrm{L}^{+}, \mathrm{L}^{-}$and $\mathrm{C}$ lines are presented in figure 1 . The changes in TNY-3 mean in theses lines over generations were due to the effects of selection plus fluctuated environments. Direct response to selection (R) in each line, and cumulated response $(\mathrm{Ra})$ and SDa for the divergence, are given in table 5. After 8 generations of selection, the Ra was 3.80 young born in the $L+$ line and -3.44 in the $L-$ line when expressed as deviations from the: control line.

\section{TABle 5}

Response *, selection differential and realized heritability.

Réponse à la sélection, différentielle et héritabilité réalisée.

\begin{tabular}{|c|c|c|c|c|c|}
\hline \multirow{3}{*}{ Generation } & \multicolumn{5}{|c|}{ Line } \\
\hline & \multirow{2}{*}{$\frac{\mathbf{L}+}{\mathbf{R}}$} & \multirow{2}{*}{$\frac{\mathrm{L}-}{\mathbf{R}}$} & \multicolumn{3}{|c|}{ Divergence } \\
\hline & & & Ra. & SDa. & $\mathrm{h}_{\mathrm{r}} \pm \mathrm{S} . \mathrm{E} . * *$ \\
\hline$\ldots \ldots \ldots \ldots$ & -3.05 & -2.30 & -0.75 & 11.68 & \\
\hline$\ldots \ldots \ldots \ldots$ & 3.58 & -0.67 & 3.50 & 22.08 & \\
\hline$\ldots \ldots \ldots \ldots$ & 2.04 & 1.20 & 3.97 & 35.26 & $0.27 \pm 0.07$ \\
\hline$\ldots \ldots \ldots \ldots \ldots$ & 0.71 & 1.34 & 3.71 & 45.40 & $0.21 \pm 0.05$ \\
\hline$\ldots \ldots \ldots \ldots$ & 0.10 & -2.07 & 5.88 & 51.80 & $0.23 \pm 0.04$ \\
\hline$\ldots \ldots \ldots \ldots \ldots$ & 1.38 & -0.32 & 7.58 & 60.11 & $0.25 \pm 0.04$ \\
\hline$\ldots \ldots \ldots \ldots \ldots$ & -2.86 & -3.87 & 8.59 & 67.07 & $0.26 \pm 0.03$ \\
\hline$\ldots \ldots \ldots \ldots \ldots$ & 1.90 & 3.25 & 7.25 & 71.47 & $0.24 \pm 0.03$ \\
\hline \multicolumn{6}{|c|}{$\begin{array}{l}\text { Expressed as deviations from the control line. } \\
\text { The } h_{r}^{2} \text { was calculated by doubling the regression coefficient of } R \text {. on SDa. }\end{array}$} \\
\hline
\end{tabular}




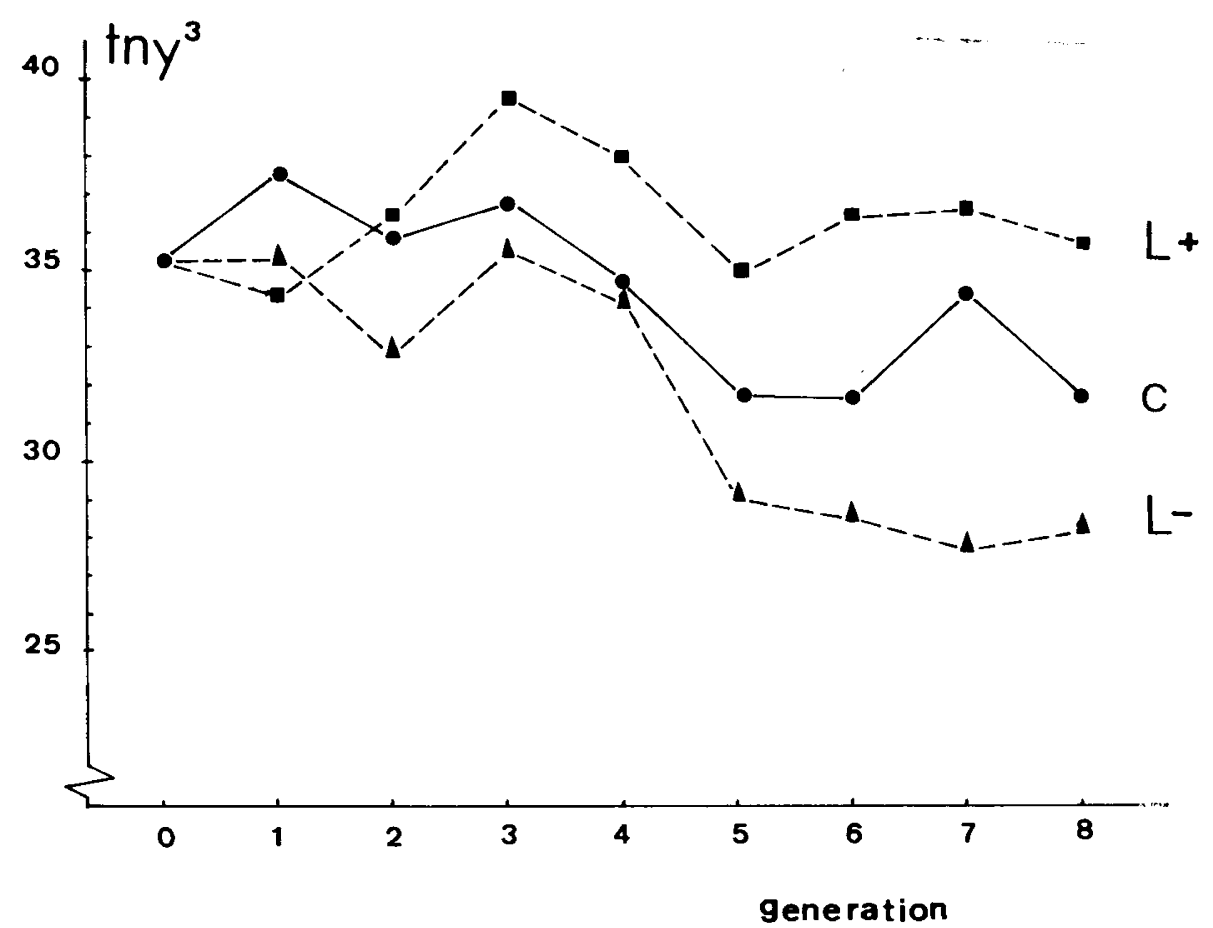

Fig. 1

Mean for TNY-3 in $L^{+}, L^{-}$and $C$ line.

Evolution du TNY-3 dans les lignées $L^{+}, L^{-}$et $C$.

The realized heritability for the TNY-3 was $0.24 \pm 0.03$ for the divergence between $\mathrm{L}^{+}$and $\mathrm{L}^{-}$lines when estimated with the data from 8 generations of selection. Realized heritabilities for the divergence, estimated every generation up to generation 8 , are given also in table 5 . Realized heritability was $0.28 \pm 0.05$ for the $L^{+}$line and $0.21 \pm 0.05$ for the $\mathrm{L}^{-}$when estimated using the data from 8 generations.

\section{Correlated response to selection and realized genetic correlation}

1. Between TNY-3 and 1st, 2nd and 3rd litter size

The means of the 1st (FLS), 2nd (SLS) and 3rd (TLS) litter for the L+, Land $\mathrm{C}$ lines in the 8 generations of selection are given in table 6 . Correlated responses per generation for litter size at 1 st, 2 nd and 3 rd parity were $0.18 \pm 0.11,0.22 \pm 0.07$ and $0.28 \pm 0.07$ in the $L+$ line and $0.18 \pm 0.11,0.13 \pm 0.06$ and $0.01 \pm 0.07$, respectively in the $\mathrm{L}-$ line. The realized genetic correlations $\left(\mathrm{r}_{\mathrm{Gr}}\right)$ between the TNY-3 and the FLS, between TNY-3 and the SLS, and between TNY-3 and the TLS were $0.82 \pm 0.08,0.50 \pm 0.12$ and $0.60 \pm 0.11$, respectively (table 8 ). 
TABLE 6

Mean of litter size of the 1st, 2nd and 3rd parity in the $L^{+}, L^{-}$and $C$ line.

Prolificité des lignées $\mathrm{L}^{+}, \mathrm{L}^{-}$et $C$ lors des 3 premières portées.

\begin{tabular}{|c|c|c|c|c|c|c|c|c|c|c|}
\hline \multirow{2}{*}{ Line } & \multirow{2}{*}{ Litter } & \multicolumn{9}{|c|}{ Generation } \\
\hline & & 0 & 1 & 2 & 3 & 4 & 5 & 6 & 7 & 8 \\
\hline \multirow{3}{*}{$\mathrm{C}$} & 1st $\ldots$ & 11.35 & 13.06 & 12.65 & 12.49 & 11.33 & 9.53 & 12.09 & 11.11 & 11.07 \\
\hline & 2nd ... & 12.59 & 12.83 & 12.13 & 12.92 & 12.43 & 11.65 & 10.71 & 10.91 & 10.90 \\
\hline & 3rd ... & 12.62 & 11.37 & 11.09 & 11.94 & 10.89 & 9.52 & 10.00 & 10.42 & 9.75 \\
\hline \multirow{3}{*}{$\mathbf{L}+$} & 1st $\ldots$ & 11.35 & 12.22 & 12.71 & 12.60 & 12.09 & 12.18 & 12.89 & 11.36 & 11.98 \\
\hline & 2nd & 12.59 & 12.00 & 12.39 & 13.51 & 13.28 & 12.32 & 11.50 & 13.09 & 11.68 \\
\hline & 3rd ... & 12.62 & 10.35 & 10.90 & 13.07 & 12.21 & 10.21 & 11.87 & 11.76 & - \\
\hline \multirow{3}{*}{ L- } & 1st & 11.35 & 12.63 & 11.27 & 11.07 & 11.06 & 10.20 & 10.74 & 8.77 & 9.27 \\
\hline & 2nd & 12.59 & 12.13 & 11.62 & 12.79 & 11.21 & 10.13 & 10.39 & 10.04 & 9.36 \\
\hline & 3 rd & 12.62 & 10.23 & 11.03 & 12.14 & 11.20 & 9.56 & 8.48 & 9.93 & 9.76 \\
\hline
\end{tabular}

After several generations changes were found in the phenotypic correlations $\left(r_{p}\right)$ among the size of the 1st, 2nd and 3rd litters. Phenotypic correlations in the base population and those of the selected lines in generation 7 are given in table 7 . The selection resulted in increased phenotypic correlations between the size of the 1 st and 2nd litter, but $r_{p}$ between the size of the $(1 s t+2 n d)$ litter and the 3rd one was negative.

\section{TABLE 7}

Phenotypic correlations among litter size.

Corrélations phénotypiques entre les tailles de portée aux 3 premières mises bas.

\begin{tabular}{|c|c|c|c|}
\hline Litter size & Line $\mathbf{L}+*$ & Line $\mathrm{L}^{-*}$ & Base population \\
\hline $\begin{array}{l}\text { 1st }- \text { 2nd } \ldots \ldots \cdots \cdots \cdots \\
\text { 2nd }- \text { 3rd } \ldots \ldots \cdots \cdots \cdots \\
\text { 1st }- \text { 3rd } \ldots \ldots \cdots \cdots \cdots \\
(1 \text { st }+ \text { 2nd })-3 \text { 3rd } \ldots \cdots \cdots \cdots\end{array}$ & $\begin{array}{r}0.48 \\
-0.18 \\
-0.13 \\
-0.25\end{array}$ & $\begin{array}{r}0.38 \\
-0.04 \\
-0.39 \\
-0.23\end{array}$ & $\begin{array}{l}0.07 \pm 0.07 \\
0.11 \pm 0.11 \\
0.02 \pm 0.06 \\
0.14 \pm 0.10\end{array}$ \\
\hline
\end{tabular}

* Selected line at generation 7 .

\section{Between TNY-3 and body weight}

To study the correlated responses in body weight, 3 traits were analysed : 3 and 6 week body weights and 3-6 week body weight gain. Regression of the divergence between $\mathrm{L}^{+}$and $\mathrm{L}^{-}$means on generations showed an average increase per generation of $0.08 \pm 0.32 \mathrm{~g}$ and $0.14 \pm 0.04 \mathrm{~g}$ for 3 -week body weight and 3-6 week body 
weight gain, respectively. Correlated responses per generation for 6 -week body weight were $0.12 \pm 0.07 \mathrm{~g}$ and $-0.22 \pm 0.13 \mathrm{~g}$ in the $\mathrm{L}^{+}$and $\mathrm{L}^{-}$lines, respectively. Realized genetic correlations are given in table 8 .

TABLE 8

Realized genetic correlations between TNY-3 and other traits.

Corrélation génétique réalisée entre le nombre total de nés et d'autres caractéristiques.

\begin{tabular}{l|c} 
Traits & $\mathrm{r}_{\mathrm{G}_{\mathrm{r}}} \pm \mathrm{S.E}$. \\
\hline 1st litter size $\ldots \ldots \ldots \ldots \ldots \ldots$ & $0.82 \pm 0.08$ \\
2nd litter size $\ldots \ldots \ldots \ldots \ldots$ & $0.50 \pm 0.12$ \\
3rd litter size $\ldots \ldots \ldots \ldots \ldots$ & $0.60 \pm 0.11$ \\
3-week body weight $\ldots \ldots \ldots \ldots$ & $0.50 \pm 0.13$ \\
6-week body weight $\ldots \ldots \ldots \ldots$ & $0.65 \pm 0.04$ \\
Gain 3-6 week $\ldots \ldots \ldots \ldots \ldots$ & $0.26 \pm 0.14$
\end{tabular}

\section{Discussion}

\section{A. Estimation of heritability}

Heritability estimates for litter size decreased with litter order. That is in agreement with the results of some studies in pigs (Bolet \& FElgines, 1981), (JOHANSON \& KENNEDY, 1982). It seems that relative to the size of 1st litters the sizes of 2 nd and 3rd litters are more influenced by environmental factors such as interval between litters, number of young born in the previous parity, etc. On the other hand, the heritability estimate for TNY-3 was higher than that for each parity. This agrees with the results obtained under a permanent breeding system as given in this study, e.g. Nagai \& Yokoyama (1982) who obtained an estimate of 0.40 for the number of young born during a period of 200 days and 0.32 for the average of litter size per parity, and STRANG \& KING (1970) who found a higher heritability as the number of litters included in the estimation increased in swine.

\section{B. Selection differential}

One of the problems that appeared in the selection process for the TNY-3 was the impossibility of exerting large selection pressure. The selection intensity (i) in the $\mathrm{L}^{+}$line $(0.81)$ was low when compared with that obtained by BAKKER et al., (1978) who selected for 1st litter size (1.54) without standardizing number of young and, thus having more offspring available per dam. Besides, the low selection differential in our experiment was caused by the procedure that females that did not produce 3 births during 85 days were discarded. The percentage of females discarded was not very high for the 1st few generations, but increased through the later generations causing a gradual decrease in SDr in the selection process. A reduction 
in the contribution of the 3rd litter to DSr was also observed. One possible cause of the lower contribution of the 3rd litter is that the permanent breeding system causes a greater stress in some of the females that reach the 3rd parity.

\section{Selection response and realized heritability}

The response of TNY-3 was variable through the 8 generations and negative response were obtained in some generations. This result was due to the small number of females used for each generation ( 50 females per line), and to the low DSr.

The $h_{r}^{2}$ obtained after 8 generations of divergent selection was $0.24 \pm 0.03$, which is higher than that found in most of selection experiments by the litter size of the 1st parity : $0.14 \pm 0.02$ (FALCONER, 1960 b) ; $0.06 \pm 0.02$ (DALTON \& BYWATER, 1963) ; $0.16 \pm 0.06$ (EKLUND \& BRADFORD, 1977). This could be explained by the fact that in all of these experiments a larger number of generations (12-29) was used. The factors that may have influenced the $h_{r}^{2}$ estimate are :

\section{Litter size standardization}

Prolificacy selection without standardizing the litter size is less effective. Maternal effects may be negatively correlated to direct genetic effect in mice and the other multiparous species (VANGEN, 1981). Standardizing litter size at birth is a way of overcoming the difficulty due to maternal effects (Ollivier, 1982). Falconer (1960 b) and BAKKER et al. (1978) did not standardize the litter size and obtained a $\mathrm{h}_{\mathrm{r}}^{2}$ of $0.14 \pm 0.02,0.11 \pm 0.02$ respectively.

\section{Trait by which the selection is performed in order to improve the litter size}

Strang \& King (1970), Bolet \& Legault (1982) and Ollivier (1982) reported in swine that $h_{r}^{2}$ increases as the number of parities increases, especially when repeatability is low. MATHERON (1982) who selected for litter size of 3 parities in rabbit, obtained a realized heritability $(0.22$ and 0.25$)$ similar to that found in our experiment. We assume that in mice and other multiparous species, some of genes influencing the size of each litter are different since the genetic correlations between then are not high.

\section{Age at mating}

The age at mating influences the prolificacy and the selection effectiveness through body weight and the ovulation rate (KENNEDY \& KENNEDY, 1972). When mice are mated at an early age ovulation rate is a limiting factor of 1 st litter size while the uterine capacity is critical in the following litters (FINN, 1963). Improved ovulation rate does not increase litter size (BRADFORD, 1969). In our experiment, mice were mated at a later age (50-60 days) when females were fully mature : our NMRI strain is quite percocious.

4. Number of selection generations in which the $h_{r}^{2}$ is calculated

BRADFORD (1968), in a selection experiment to improve the 1st litter size, obtained after 8 generations of selection $a h_{r}^{2}$ of $0.25 \pm 0.05$ (similar to the one we obtained 
with the same number of generations), and of $0.13 \pm 0.07$ and $0.22 \pm 0.06$ after 11 generations (in 2 replicates). The selection response decreased with generations, because of the progressive decrease of the additive genetic variation of this trait. In all experiments selecting for 1 st litter size, an association between $h_{r}^{2}$ and number of generations with response exists. In this way, when selection is very effective, the $\mathrm{h}_{\mathrm{r}}{ }^{2}$ is high and the response subsists during a few generations (BRADFORD, 1968; EKLUND \& BRADFORD, 1977). On the other hand, if $h_{r}^{2}$ is low, the response continues for more generations of selection (FALCONER, $1960 \mathrm{~b}$; BAKKER et al., 1978 and DALTON \& BYWATER, 1963). The conclusion of that is the little variability of fertility, since most of the additive genetic variation had been fixed by the effect of the natural selection on the reproductive capacity.

\section{Direction of selection}

The heritability in $\mathrm{L}+$ line, $(0.28 \pm 0.05)$ was higher than that of the $\mathrm{L}-$ line $(0.21 \pm 0.05)$. The result is not in good agreement with that of FALCONER $(1960 \mathrm{~b})$ who obtained a higher $h_{r}^{2}$ in the $L-$ line $(0.23 \pm 0.02)$ than in the $L+$ line $(0.08 \pm 0.02)$, after 20 generations of divergent selection for 1 st litter size. This difference may have been due to the fact that we have selected indirectly for fecundity improvement in both lines, since we only make the selection among those females that in a period of 85 days have given 3 litters. Fertility could be correlated with litter size and made negative selection less effective. This effect is not detected in FALCONER's experiment selecting for the 1st litter size, whereas it was observed in our experiment selecting for the first 3 litters.

\section{Correlated response in reproductive traits}

Selection for TNY-3 modified the size of each litter in a different degree when the females were subjected to a permanent breeding method. Selection gave response in the 1st and 2nd birth and that increment caused an environmental effect (negative in the $\mathrm{L}^{+}$and positive in the $\mathrm{L}^{-}$lines) on the 3 rd litter size. This effect was also detected by WALLINGA \& BAKKER (1978) who selected females under permanent breeding system to increase litter size in the 1st birth. They found a decrease in size of the 2nd and 3rd litters while the control line was unchanged. WALlinga \& BAKKER (1978) and FINN (1963) considered that the decrease was resulted from overloading in the uterus, as seen by the embryonic mortality, to maintain large litters. HARKNESS (1956) and KAO et al. (1962) showed that the synthesis of collagen is the limiting factor.

The disadvantage of selection for the 1st litter size is that the improvement of this 1 st birth is not maintained in the following ones and at the same time a reduction in lifetime reproduction occcurs (LUXFord \& BEILHARZ, 1982 and SCHÜLER \& BüNGER, 1982). LUXFORD \& BEILHARZ (1982) selected 2 lines (A and B) of mice at 1st parity for total litter weight at birth and for the number of young alive respectively. For each selected line a response was obtained but, overall lifetime reproduction was reduced in both lines, for the selected traits.

In our experiment the increment due to selection for TNY-3 was not large, but this response remained positive in the size of the 2 nd and 3 rd litters. Selection for the 1st litter size acts through the changes in ovulation rate and embryonic mortality (FALCONER, $1960 \mathrm{~b}$ ), but the ovulation rate increase only affects the 1 st litter size and not the following ones (BRADFORD, 1969). The limiting factor of 2nd, 3rd and following 
litter sizes is not only the ovulation rate but also the uterine capacity, in the multiparous species (VANGEN, 1981), which controls litter size through embryonic mortality, particulary in a permanent breeding system (WALlingA \& BAKKER, 1978). Selection for the 1st litter size does not always improve uterine capacity. Selection for the size of several litters has the disadvantage that selection pressure is smaller. However this effect could be counteracted in livestock breeding by increasing the population size.

From these results we can conclude that for improving prolificacy in multiparous species without reducing the reproduction lifetime, either the amount of young born in a period of time or the total number of young born in several litters should be considered. According to BoleT \& LEGAULT (1982) a selection index should be used with the size of several litter, especially when the phenotipic correlation between them is not high.

\section{E. Correlated response in body weight}

Litter size may have influenced body weight through its correlation with ovulation rate. The change in litter size may be due to a modification in ovulation rate (in this last case there would also be changes in body weight). The $\mathrm{r}_{\mathrm{Gr}}$ between TNY-3 and 3-week body weight was high $(0.05 \pm 0.13)$ and also between TNY-3 and 6-week body weight $(0.65 \pm 0.04)$. BAKKER et al. (1978) and FAlCONER (1960 b) did not find significant changes in body weight when selecting for the 1st litter size, but JOAKIMSEN \& BAKER (1977) obtained $\mathrm{a}_{\mathrm{Gr}}$ of 0.6 and EISEN (1978) obtained a $\mathrm{r}_{\mathrm{Gr}}$ of $0.52 \pm 0.10$. That is in good agreement with our results. A lack of correlated response in body weight (FALCONER, $1960 \mathrm{~b}$ ), could be explained by the fact that the litter size was not standardized to remove the negative environmental correlation between litter size and body weight.

\section{Acknowledgements}

The authors are indebted to Professor E.J. EISEN for the reading and comment of the manuscript.

Received October 20, 1983. Accepted December 12, 1984.

\section{References}

Bakker H., Wallinga J.H., Politiek R.D., 1978. Reproduction and body weight of mice after long-terme selection for large litter size. J. Anim. Sci., 46, 1572-1580.

Bateman N., 1966. Ovulation and post-ovulation losses in strains of mice selected for large and small litters. Genet. Res., 8, 229-241.

BECKER W.A., 1967. Manual of procedures in quantitative genetics. 130 pp., Washington State University Press. Pullman.

Bolet G., Felgines C., 1981. Héritabilité de la prolificité, corrélations phénotypiques et génétiques entre les quatre premières portées des truies de race Large White. 32nd Annual Meeting of the European Association for Animal Production. Zagreb, August 31-September 3, 1981. Génét. Sél. Anim., 14, 121-122 (abstr.)

Bolet G., Legault C., 1982. New aspects of genetic improvement of prolificacy in pigs. 2nd World Congress on Genetics Applied to Livestock Production. Madrid, October 4-8, $1982,5,548-567$. 
BRADFORD G.E., 1968. Selection for litter size in mice in the presence and absence of gonadotropin treatment. Genetics, 58, 283-295.

BRADFORD G.E., 1969. Genetic control of ovulation rate and embryo survival in mice. I.

Response to selection. Genetics, 61, 905-921.

Dalton D.C., Bywater T.L., 1963. The effects of selection for litter size and litter weight at weaning in mice maintained on two diets. Anim. Prod., 5, 317-326.

EISEN E.J., 1978. Single-trait and antagonistic index selection for litter size and body weight in mice. Genetics, 88, 781-811.

EkLUNd J., BradFord G.E., 1977. Genetic analysis of a strain of mice plateaued for litter size. Genetics, 85, 529-542.

FALCONER D.S., 1960 a. Introduction to quantitative genetics. 340 pp., Ronald Press, New York.

Falconer D.S., 1960 b. The genetics of litter size in mice. J. Cellul. Comp. Physiol., 56, 153-167.

FinN C.A., 1963. Reproductive capacity and litter size in mice. J. Reprod. Fert., 7, 707-711.

Harkness M.L.R., Harkness R.D., 1956. The distribution of the growght of collagen in the uterus of the pregnant rat. J. Physiol., 132, 492-501.

HiLl W.G., 1971. Design and efficiency of selection experiments for estimating genetic parameters. Biometrics, 27, 293-311.

HILL W.G., 1972 a. Estimation of realised heritabilities from selection experiments. I. Divergent selection. Biometrics, 28, 747-766.

HILl W.G., 1972 b. Estimation of realised heritabilities from selection experiments. II. Selection in one direction. Biometrics, 28, 767-780.

Joakimsen O., Baker R.L., 1977. Selection for litter size in mice. Acta Agric. Scand., 27, 301-318.

JOHANSSON K., KENNEDY B.W., 1982. Estimation of genetic parameters of fertility traits in pigs. 2nd World Congress on Genetics Applied to Livestock Production. Madrid, October 4-8, 1982, 7, 503-508, Editorial Garsi, Madrid.

Kao K.Y.T., Chen Lu L.S., McGavck T.H., 1962. Connective tissue. VI. Synthesis of collagen by rat uterine slices. Prod. Exp. Biol., 109, 4.

KENNEDY T.G., KenNEDY J.P., 1972. Effects of age and parity on reproduction in young female mice. J. Reprod. Fert., 28, 78-84.

LUXFord B.G., BeILHARZ R.G., 1982. The effect of selection on reproductive performance early in life on lifetime performance. 2nd World Congress on Genetics Applied to Livestock Production. Madrid, October 4-8, 1982, 7, 479-482, Editorial Garsi, Madrid.

Matheron G., 1982. Genetics and selection of litter size in rabbit. 2nd World Congress on Genetics Applied to Livestock Production. Madrid, October 4-8, 1982, 6, 481-498, Editorial Garsi, Madrid.

Nagai J., Yokoyama A., 1982. Lifetime performance in mice. 2. Reproduction. 2nd World Congress on Genetics Applied to Livestock Production. Madrid, October 4-8, 1982, 7, 39-43, Editorial Garsi, Madrid.

Ollivier L., 1982. Selection for prolificacy in the pig. Anim. Breed. Abst., 3, 383-388.

ROBERTS R.C., 1965. Some contributions of the laboratory mouse to animal breeding research. Part II. Anim. Breed. Abst., 33, 515-526.

RoBERTSON A., 1959. Experimental desing in the evaluation of genetic parameters. Biometrics, 15, 219-226.

Rutledge J.J., Eisen E.J., Legates J.E., 1973. An experimental evaluation of genetic correlation. Genetics, 75, 709-726.

SCHüleR L., BüNGER L., 1982. Die reproduktive Lebensleistung auf Fruchtbarkeit selektierter Labormauslinien. Arch. Tierzucht., 25, 275-281.

Strang G.S., KING J.W.B., 1970. Litter productivity in Large White pigs. 2. Heritability and repeatability estimates. Anim. Prod., 12, 235-243.

VANGen O., 1981. Problems and possibilities for selection for fecundity in multiparous species. Anim. Breed. Abst., 2, 257-263.

Wallinga J.H., BaKKer H., 1978. Effect of long-term selection for litter size in mice on life-time reproduction rate. J. Anim. Sci., 46, 1563-1571. 